\title{
Decadal increase in seagrass biomass and temperature at the CARICOMP site in Bocas del Toro, Panama
}

\author{
Jorge M. López-Calderón ${ }^{1 *}$, Héctor M. Guzmán², Gabriel E. Jácome ${ }^{2}$ \& Penélope A. G. Barnes ${ }^{3}$ \\ 1. Programa de Botánica Marina, Departamento de Biología Marina, Universidad Autónoma de Baja California Sur, \\ Apdo. Postal 19-B, La Paz, Baja California Sur, 23080, México; jlopez@uabcs.mx \\ 2. Smithsonian Tropical Research Institute, Box 0843-03092, Panama, Republic of Panama; \\ guzmanh@si.edu,jacomeg@si.edu \\ 3. Bermuda Institute of Ocean Sciences, 17 Biological Station, St. George's, GE 01, Bermuda; pbarnes3@telus.net \\ * Correspondence
}

\author{
Received 22-I-2013. Corrected 30-IV-2013. Accepted 31-V-2013.
}

\begin{abstract}
The Caribbean Coastal Marine Productivity Program (CARICOMP) was launched in 1993 to study regional long-term interactions between land and sea, taking standardized measurements of productivity and biomass of mangroves, coral reefs and seagrasses. Since 1999 continuous measurements of seagrass (Thalassia testudinum) parameters as well as environmental data have been recorded in Caribbean Panama. Replicate stations were selected near the Smithsonian Tropical Research Institute in Bocas del Toro. Sediment cores and quadrants were placed there to estimate biomass and productivity, respectively. Mean values for productivity, standing crop, turnover rate, total dry biomass, and Leaf Area Index were $1.74 \mathrm{gDW} / \mathrm{m}^{2} / \mathrm{d}, 66.6 \mathrm{gDW} / \mathrm{m}^{2}$, $2.62 \% / \mathrm{d}, 1481 \mathrm{gDW} / \mathrm{m}^{2}$, and 4.65, respectively. Total dry biomass (shoots, rhizomes and roots) and LAI of $T$. testudinum increased significantly during the study period. Mean values for total rainfall, Secchi disk depth, sea surface temperature, and salinity were $3498 \mathrm{~mm}, 8.24 \mathrm{~m}, 28.79^{\circ} \mathrm{C}$, and $32.26 \mathrm{psu}$, respectively. Sea surface temperature was the only environmental variable with a statistically significant change, increasing from 1999 to 2010. Correlation between sea surface temperature and T. testudinum parameters (total biomass and LAI) were both positive and significant. Human population has increased dramatically over the last ten years in Bocas del Toro region, increasing pressure (deforestation, runoff, wastewater) over coastal ecosystems (seagrasses, mangroves, coral reefs). Change in the abundance of $T$. testudinum may be linked to ocean warming, as a consequence to satisfy plant's metabolic requirements, although other local factors need to be analyzed (reduced grazing and increased eutrophication). A further warming of the ocean could have a negative effect on $T$. testudinum population, increasing respiratory demands and microbial metabolism.Rev. Biol. Trop. 61 (4): 1815-1826. Epub 2013 December 01.
\end{abstract}

Key words: Caribbean, Panama, CARICOMP, time-series, productivity, Thalassia testudinum.

Seagrass meadows are a key ecosystem of the coastal zone, they are highly productive, fixing $15 \%$ of the carbon fixed by all oceanic primary producers (Duarte \& Chiscano, 1999). Play a fundamental role as nursery and refuge for fish and other marine species (Verweij, Nagelkerken, De Graaff, Peeters, Bakker, \& Van der Velde, 2006; Heck Hays \& Orth, 2003), enhance diversity (Casares \& Creed, 2008), are a source of food for endangered species (Cuevas, Liceaga-Correa, \& Garduño-Andrade, 2007), and serve as a major sink for atmospheric carbon, capturing up to $112 \mathrm{Tg} / \mathrm{y}$ (Nellemann, Corcoran, Duarte, Valdés, de Young, \& Fonseca, 2009; Duarte, Marbà, Gacia, Fourqurean, Beggins, \& Barrón, 2010; Kennedy, Beggins, Duarte, Fourqurean, Holmer, \& Marbà, 2010; Russell, Connell, Uthicke, Muehllehner, Fabricius, \& Hall-Spencer, 2013). Seagrass meadows also 
form fundamental ecological connections with other tropical coastal ecosystems, including mangrove forests and coral reefs (Nagelkerken, Roberts, Van der Velde, Dorenbosch, Van Riel, \& Cocheret de la Morinière, 2002; Mumby, Edwards, Arias-González, Lindeman, Blackwell, \& Gall, 2004; Nagelkerken \& Van der Velde, 2004).

Worldwide, seagrass habitats have decreased for more than three decades (Orth, Carruthers, Dennison, Duarte, Fourqurean, \& Heck, 2006; Short, Polidoro, Livingstone, Carpenter, Bandeira, \& Bujang, 2011) and the current habitat loss rate is estimated to be $110 \mathrm{~km}^{2} / \mathrm{y}$, this is a dramatic increase considering that between 1879 and 2006 the decrease rate was estimated at $27 \mathrm{~km}^{2} / \mathrm{y}$ (Waycott, Duarte, Carruthers, Orth, Dennison, \& Olyarnik, 2009). This loss has been attributed mostly to human development of the coastal zone, which poses threats such as dredging, housing development, and boat traffic (Short \& Burdick, 1996, Erftemeijer \& Robin Lewis, 2006, Björk, Short, Mcleod, \& Beer, 2008; Halpern, Walbridge, Selkoe, Kappel, Micheli, \& D’Agrosa, 2008). Dominant seagrass species in the Caribbean is turtlegrass Thalassia testudinum (Banks ex König) which covers and approximate area of $2790 \mathrm{~km}^{2}$ (Green \& Short, 2003), although the most recent estimate (Wabnitz, Andréfouët, Torres-Pulliza, Müller-Karger, \& Kramer, 2008) set the seagrass extension for the wider Caribbean at almost $70000 \mathrm{~km}^{2}$. In Caribbean Panama, human pressure on coastal ecosystems continues to build through deforestation of vast coastal areas for touristic, industrial, or urban purposes (Guzman, 2003; Fulweiler, Rabalais, \& Heiskanen, 2012). Deforestation results in increased runoff of sediments and nutrients into the adjacent marine systems leading to a reduction in light availability and an increase in eutrophication (Burkholder, Tomasko, \& Touchette, 2007; Fulweiler et al., 2012).

Many economic and cultural activities in coastal communities rely on marine resources such as seagrass meadows, therefore, in recent years our knowledge of the dynamics of seagrass resources in the Caribbean has improved
(Alcolado, Alleng, Bonair, Bone, Buchan, \& Bush, 2001; Creed, Phillips, \& Tussenbroek, 2003; Harborne, Mumby, Micheli, Perry, Dahlgren, \& Holmes, 2006; Wabnitz et al., 2008). The need for long-term monitoring is crucial to evaluate possible impacts of human and natural disturbances. In 1993 the Caribbean Coastal Marine Productivity Program (CARICOMP) was launched to study regional long-term interactions between land and sea (Alcolado et al., 2001, CARICOMP, 2001). As a result of this project, information of turtlegrass meadows from different regions of the Caribbean has been published. It was found that nutrient enrichment is having a negative effect on T. testudinum, decreasing its coverage and biomass in Bon Accord Lagoon, Tobago (Juman, 2005). Fonseca, Nielsen, \& Cortés (2007) reported a decrease in both biomass and productivity as a consequence of ocean warming in Cahuita National Park, Costa Rica, from 1999 to 2005, with nutrient loading from deforestation and local pollution as potential additional threats to T. testudinum population. Murdoch, Glasspool, Outerbridge, Ward \& Gray (2007) analyzed data from 1962 to 2004 and found a widespread decline in Bermuda meadows located at the rim of the reef and in the lagoon, while inshore and nearshore meadows remain relatively constant. A similar result was published by Krupp, Cortés, \& Wolff (2009) for Cahuita National Park, stating that although turtlegrass meadows are in good health, it is probable that they are at their maximum level of tolerance for environmental stress, based on the increasing abundance of epiphytes and macroalgae. Recently, Van Tussenbroek, Smith, Absten, Gerace, Alcolado \& Gayle (in press) found that for the Greater Caribbean more than $60 \%$ of the CARICOMP sites show consistent signs of degradation through changes in the community structure, associated to increased nutrient input or sedimentation since the early 1990's.

Data for Caribbean Panama has not been published so far; since 1998, data on seagrass temporal variability and environmental variables have been collected at the CARICOMP site located in Bocas del Toro, Panama. This 
work represents the first report for the turtlegrass population in this area. The goal of our study was to analyze ten years of data of T. testudinum to evaluate the variability of: above-ground biomass (shoots), below-ground biomass (rhizomes and roots), standing crop, Leaf Area Index (LAI), leaf productivity and turnover rate. Possible correlations between environmental variables (seawater temperature, salinity, total rainfall, water column visibility) and seagrass productivity and abundance parameters were determined.

\section{MATERIALS AND METHODS}

Study area: Turtlegrass (T. testudinum) meadows at the CARICOMP site in Isla Colon extend from the shore into the sea to a distance of $150 \mathrm{~m}$. The CARICOMP monitoring site is near the Smithsonian Tropical Research Institute (STRI) facilities on Isla Colon in the Bocas del Toro Archipelago ( $9^{\circ} 21^{\prime} 0^{\prime}$ " N - 82 $15^{\prime} 0^{\prime}$ " W). The Archipelago lies along the Northwest Caribbean coast of Panama and is formed by numerous forested islands and two major semienclosed basins: Bahía Almirante, the location of the study site, and Laguna de Chiriquí. Rainfall in the area is quite abundant (annual mean $\sim 3000 \mathrm{~mm} / \mathrm{y}$ ) and can reduce seawater salinity to 20psu after heavy rainfall (Kaufmann \& Thompson, 2005). There are two dry seasons, February-March and September-October; highest rainfalls occur in December with a lower peak in July (Kaufmann \& Thompson, 2005).

Bahía Almirante is a relatively small lagoon $\left(446 \mathrm{~km}^{2}\right)$ with coarse sand, carbonate-dominated sediments (Carruthers, Barnes, Jacome, \& Fourqurean, 2005; D'Croz, del Rosario \& Góndola, 2005). The Bahía is surrounded by highlands and has a limited watershed, but nutrient input from river discharge maintains higher nutrient concentrations in the bay than that of the nearby ocean (Carruthers et al., 2005, D'Croz et al., 2005). Land clearing for agricultural and cattle rearing purposes or timber commodities has increased the amount of nutrient runoff into Bahía Almirante and reduced water quality in the last four decades with consequences for reef-building corals (Guzman, 2003; Aronson, MacIntyre, Wapnicks, \& O'Neill, 2004; Cramer, Jackson, Angioletti, Leonard-Pingel, \& Guilderson, 2012). Currently, Bahía Almirante can be classified as a mesotrophic lagoon ( $\sim 0.6 \mu \mathrm{gChlorophyll/L}$, Carruthers et al., 2005) according to the water quality levels reported by Green \& Webber (2003).

Circulation inside Bahía Almirante is limited because of its low tidal range $(<0.5 \mathrm{~m})$ and its reduced communication with the ocean; only three narrow passages flanked by islands or mainland (see Fig. 1, Guzman, Barnes, Lovelock, \& Feller, 2005). Seawater temperature inside Bahía Almirante fluctuates throughout the year in relation to the amount of solar radiation reaching the sea surface (Kaufmann \& Thompson, 2005). Main primary producers in the shallow $(<3 \mathrm{~m})$ and deeper (up to $15 \mathrm{~m}$ ) parts of Bahía Almirante are the seagrass T. testudinum and corals such as Agaricia tenuifolia (Guzman \& Guevara, 1998).

Seagrass data: Two research stations were located in Bahía Almirante, 12 to $18 \mathrm{~m}$ from the shore and less than $60 \mathrm{~m}$ apart from each other $\left(9^{\circ} 21^{\prime} 0^{\prime \prime} \mathrm{N}-82^{\circ} 15^{\prime} 0^{\prime}\right.$ " W, see Fig. 1, Guzman et al., 2005). For a detailed description of the sampling methods refer to CARICOMP (2001). A brief description of these methods is provided below. Turtlegrass sampling began in March 1999 and is ongoing (for this work we included until January 2010). In order to assess the local seasonal signature, sampling interval was more intense during the first campaigns, with four sampling events per year in 1999 (February, June, September, December) and three in 2000 and 2001 (January, July, October). Analysis of these data revealed that the seasonal signal (spring, summer, autumn, winter) was not significant, so the sampling frequency for subsequent years was reduced to two times per year, to capture annual variability, maximum and minimum turtlegrass 

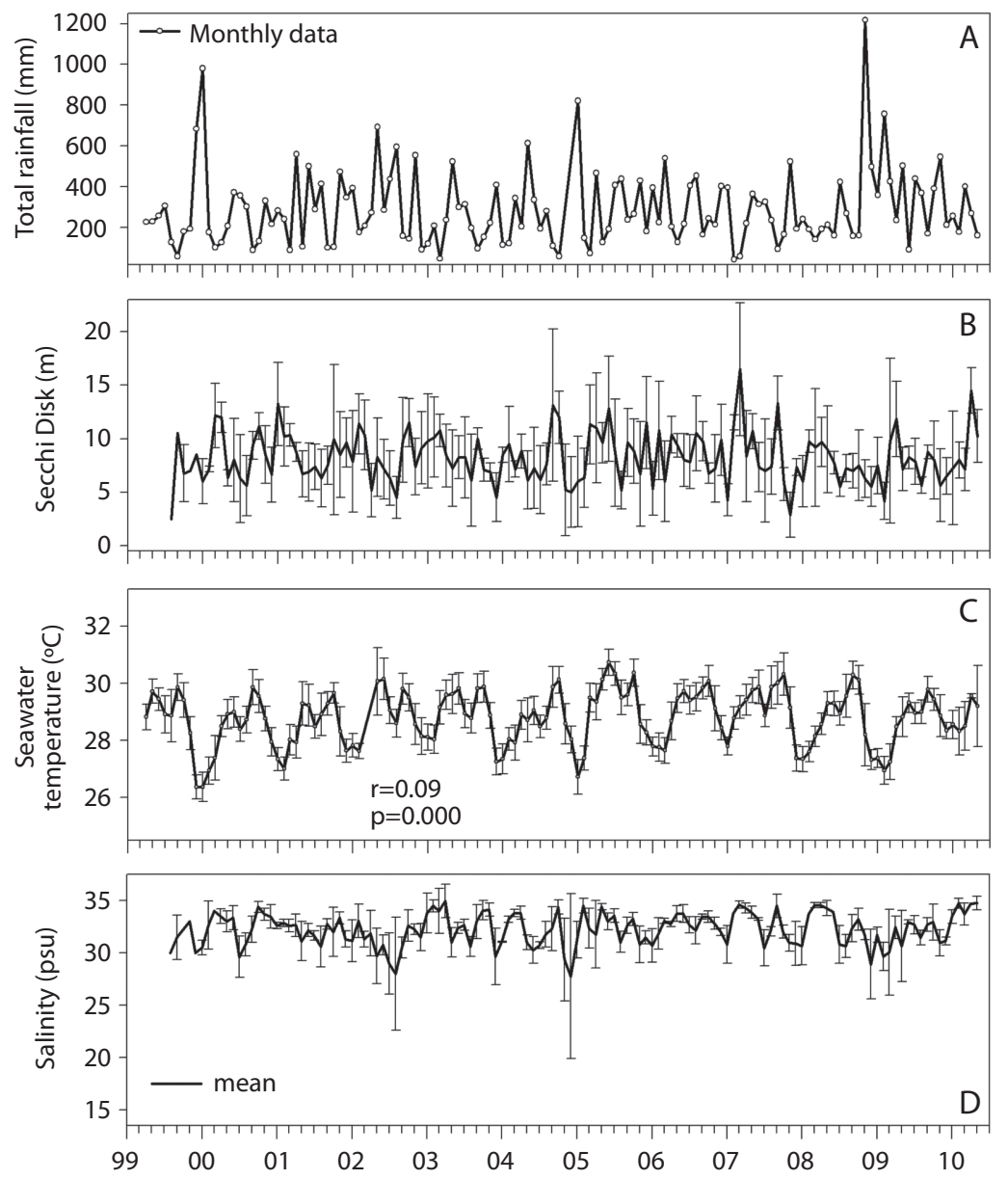

Fig. 1. Monthly rainfall and means of Secchi disk depth, seawater temperature and salinity. From April 1999 to May 2010 in Changuinola (33km Northwest of Bocas del Toro) (A) and in Isla Colon (B-D). Standard error bars for B-D. Significant Spearman Rank Correlation Coefficients are shown.

productivity. This approximately corresponded to January and July, respectively.

Core sampling: Thalassia testudinum biomass samples were extracted with a PVC corer (20 cm diameter $\mathrm{x} 77 \mathrm{~cm}$ deep). Each sample was completely cleaned of sediment and the following fractions were separated: leaves, shoots, rhizomes, and roots. All the material was dried for $48 \mathrm{~h}\left(60^{\circ} \mathrm{C}\right)$ and weighed to determine above-ground biomass (leaves and shoots), below-ground biomass (rhizomes and roots), and total biomass (the sum of both). Four samples were taken at each station.
Quadrant sampling: Productivity samples were measured with a PVC quadrant $(10 \times 20 \mathrm{~cm})$. All turtlegrass shoots inside the quadrant were perforated $2 \mathrm{~mm}$ above the sheath with a syringe needle to measure growth (an average of 18 shoots per quadrant). Marked leaves were left to grow for six to eight days, after that all shoots were harvested for further processing. Leaves were separated in three categories according to growth status (new leaves, growth on old leaves, and old leaves). Growth (productivity), standing crop (leaf biomass) and turnover rate (leaf percentage replaced daily) were estimated using corresponding 
equations (CARICOMP, 2001). Six samples were taken at each station. To estimate Leaf Area Index (LAI) five uprooted shoots were harvested from an area with similar shoot density adjacent to the sampled quadrants. Shoots were rinsed, and all leaves were cut at the level of the sheath; length and width of each leaf was determined to determine leaf surface area per shoot. The mean leaf area per shoot was multiplied by the number of shoots per quadrant to estimate leaf area of the turtlegrass. The ratio of this leaf area to the quadrant area $\left(200 \mathrm{~cm}^{2}\right)$ returns the LAI, which is a descriptor of the degree of leaf packing within the canopy (Watson, 1947).

Environmental data: Seawater surface temperature (SST), salinity and Secchi disk depth (horizontal measurements) were recorded above a seagrass meadow (average depth $2 \mathrm{~m})$ near the CARICOMP site $\left(9^{\circ} 21^{\prime} 0^{\prime \prime} \mathrm{N}\right.$ $\left.82^{\circ} 15^{\prime} 0^{\prime \prime} \mathrm{W}\right)$. A handheld YSI $85 \AA$ was used for the salinity measurements $(0.5 \mathrm{~m}$ depth), while temperature data was recorded at the bottom with a Hobo Water Temp Pro®. Salinity and Secchi disk depth (water column visibility) were recorded weekly from August 1999 to May 2010. SST was measured hourly from April 1999 to May 2010. Total rainfall was measured on a monthly basis (from April 1999 to May 2010) and provided by the Changuinola Banana Plantation, which lies $8 \mathrm{~km}$ from the shore and $20 \mathrm{~m}$ above sea level. More details about the characteristics of each of these environmental data sets can be found in Kaufmann \& Thompson (2005).

Time-series processing and statistical analyses were performed with SigmaPlot $10 \AA$. Except for the rainfall data, monthly means were calculated for each time series. Normality and equal variance were tested using Kolmogorov-Smirnoff and Levene Median statistics, respectively. Standard error and the plotted anomaly of each time series assisted in the identification of periods of highest variability. Non-parametric Spearman Rank Correlation analyses were applied to: i) identify significant inter-annual trends for each time series; ii) determine significant correlations between environmental data and seagrass data; and iii) determine which environmental variables were significantly correlated with each other.

\section{RESULTS}

\section{Productivity and biomass of T. testudi-} num: Growth (1999-2010) in Bocas del Toro had a mean value of $1.74 \mathrm{gDW} / \mathrm{m}^{2} / \mathrm{d}$, ranging from 1.07 to $5.80 \mathrm{gDW} / \mathrm{m}^{2} / \mathrm{d}$ (Fig. $2 \mathrm{~A}$ ). Productivity did not show a statistically significant $(p>0.05)$ trend with time; however, productivity values were above $6.0 \mathrm{gDW} / \mathrm{m}^{2} / \mathrm{d}$ only after 2003 (Fig. 2A). The decadal mean for standing crop (leaf biomass) was $66.60 \mathrm{gDW} / \mathrm{m}^{2}$. No significant $(\mathrm{p}>0.05)$ trend in standing crop was detected over the sampling period (Fig. 2B); minimum $\left(55.54 \mathrm{gDW} / \mathrm{m}^{2}\right)$ and maximum $\left(94.04 \mathrm{gDW} / \mathrm{m}^{2}\right)$ values corresponded to July 2004 and February 2007, respectively. Turnover rate mean (1999-2010) for the leaves of Thalassia testudinum was $2.62 \%$ /d (range, $1.58-6.06 \% / \mathrm{d}$ ), with frequent peaks throughout the time series (Fig. 2C). Although no significant $(p>0.05)$ trend was observed, before 2002 leaf percentage replaced daily were below $4.0 \% / \mathrm{d}$; in contrast, turnover rate frequently exceeded 7.0\%/d after 2002. Total biomass (leaves, shoots, rhizomes and roots) decadal mean was $1481 \mathrm{gDW} / \mathrm{m}^{2}$, ranging from $916 \mathrm{gDW} / \mathrm{m}^{2}$ (June 1999) to $2129 \mathrm{gDW} / \mathrm{m}^{2}$ (January 2008). Total biomass showed a significant increase with time at the Bocas del Toro site (Spearman Correlation Coefficient $=0.76$, $\mathrm{p}=0.000, \mathrm{df}=25$ ) (Fig. 2D). At the beginning of the time series, maximum total biomass values were $1793 \mathrm{gDW} / \mathrm{m}^{2}$ (March 1999) and $1802 \mathrm{gDW} / \mathrm{m}^{2}$ (June 2000), whereas at the end of the time series maximum values were over $40 \%$ higher, $2521 \mathrm{gDW} / \mathrm{m}^{2}$ (June 2006) and $2561 \mathrm{gDW} / \mathrm{m}^{2}$ (January 2009). The decadal mean of LAI was 4.65 (range, 3-7), with values over 19 after 2002 (Fig. 2E). Leaf Area Index showed a significant increase with time $(p=0.0139, r=0.47, d f=25)$, however, lower than the correlation observed for total biomass (Fig. 2D). 

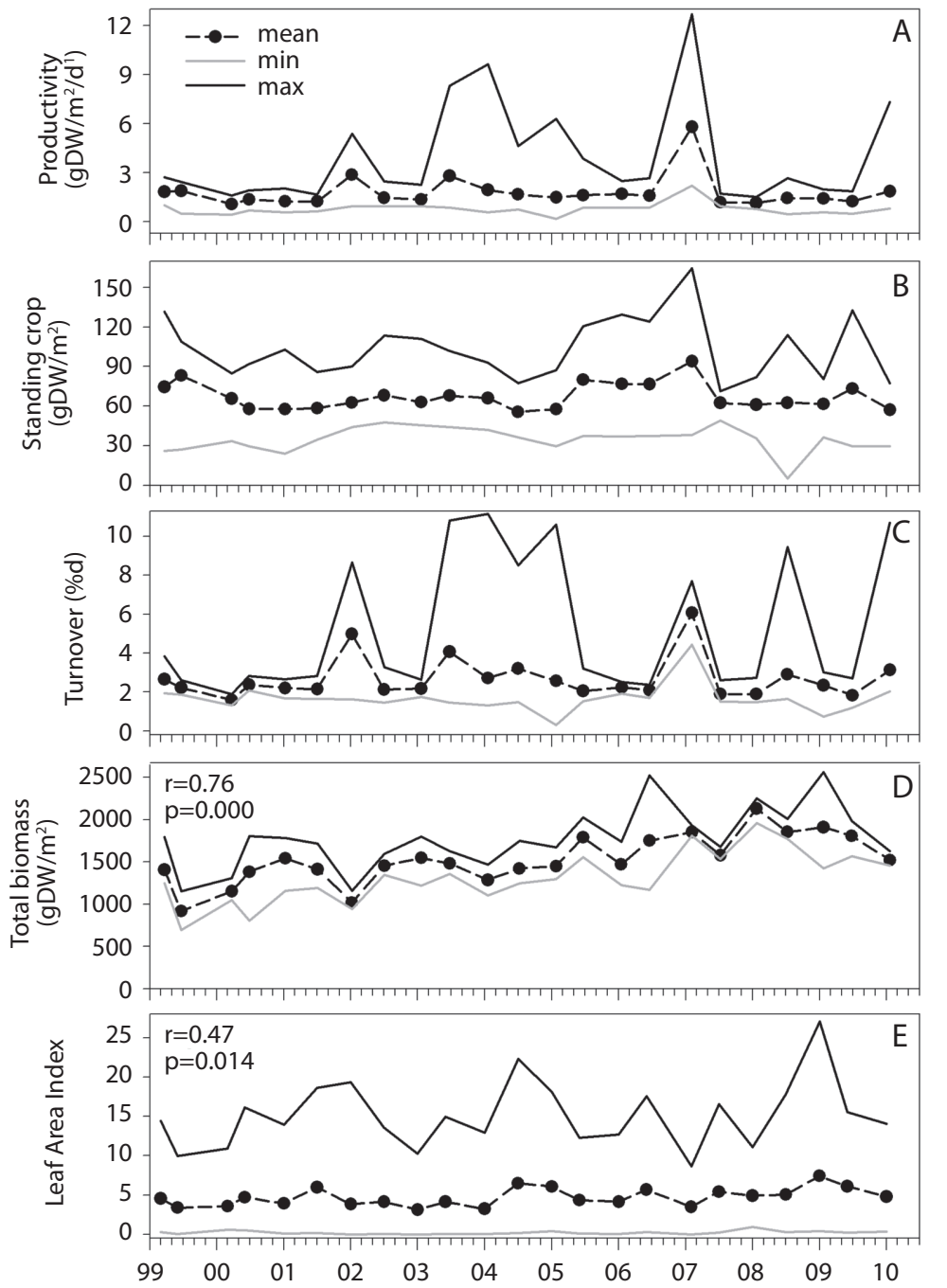

Fig. 2. Mean (dotted line) minimum (gray line) and maximum (black line) values of Thalassia testudinum productivity (A), standing crop (B), turnover rate (C), total dry biomass (D), and leaf area index (E) for 1999-2010. Significant Spearman Rank Correlation Coefficients are shown.

Environmental variables: With the exception of seawater surface temperature (SST), none of the environmental variables measured between 1999 and 2010 exhibited a significant $(p>0.05)$ correlation with time (Fig. 1). SST demonstrated a significant increase $(\mathrm{p}=0.000$, $\mathrm{df}=89$ 318) over time, with a low Spearman Rank Correlation coefficient ( $\mathrm{r}=0.09$ ).

Mean total rainfall was $3498 \mathrm{~mm}$ (1999-2010), highest values occurred in
November-December, while the lowest occurred in September-October (Fig. 3A). Mean Secchi depth was $8.24 \mathrm{~m}$, with maximum and minimum visibility in March $(10 \mathrm{~m})$ and August (6m), respectively (Fig. 3B). Decadal mean for SST was $28.79^{\circ} \mathrm{C}$, maximum values occurred from July through September and minimum values occurred from November through January (Fig. 3C). Salinity decadal mean value was 32.26psu, with three episodes of extremely 
low salinity $(<25 \mathrm{psu})$ that coincided with periods of intense rainfall (May 2002, December 2004, and December 2008) (Fig. 1A, D).

Time-series correlations: Total rainfall was negatively correlated with SST ( $\mathrm{p}=0.0043$, $\mathrm{r}=-0.25, \mathrm{df}=128$ ) and both variables were significantly correlated with salinity (rainfall: $\mathrm{p}=0.000, \mathrm{r}=-0.47, \mathrm{df}=125, \mathrm{SST}: \mathrm{p}=0.0056$, $\mathrm{r}=0.25, \quad \mathrm{df}=125$, respectively, Table 1). Moreover, water column visibility was positively correlated with $\mathrm{SST}(\mathrm{p}=0.0199, \mathrm{r}=0.21$, $\mathrm{df}=126)$ and salinity $(\mathrm{p}=0.000, \mathrm{r}=0.53, \mathrm{df}=127)$ but negatively correlated with total rainfall $(\mathrm{p}=0.000, \mathrm{r}=-0.50, \mathrm{df}=126)$. Total rainfall and salinity did not show significant correlations with any of the T. testudinum parameters. Standing crop and growth were positively correlated with SST (standing crop: $\mathrm{p}=0.0065, \mathrm{r}=0.51$, $\mathrm{df}=25$, growth: $\mathrm{p}=0.0459, \mathrm{r}=0.39, \mathrm{df}=25$, respectively), whereas water column visibility was negatively correlated with LAI ( $\mathrm{p}=0.0173$, $\mathrm{r}=-0.47, \mathrm{df}=23)$.

\section{DISCUSSION}

The environmental and biological data reported herein are a contribution to the long
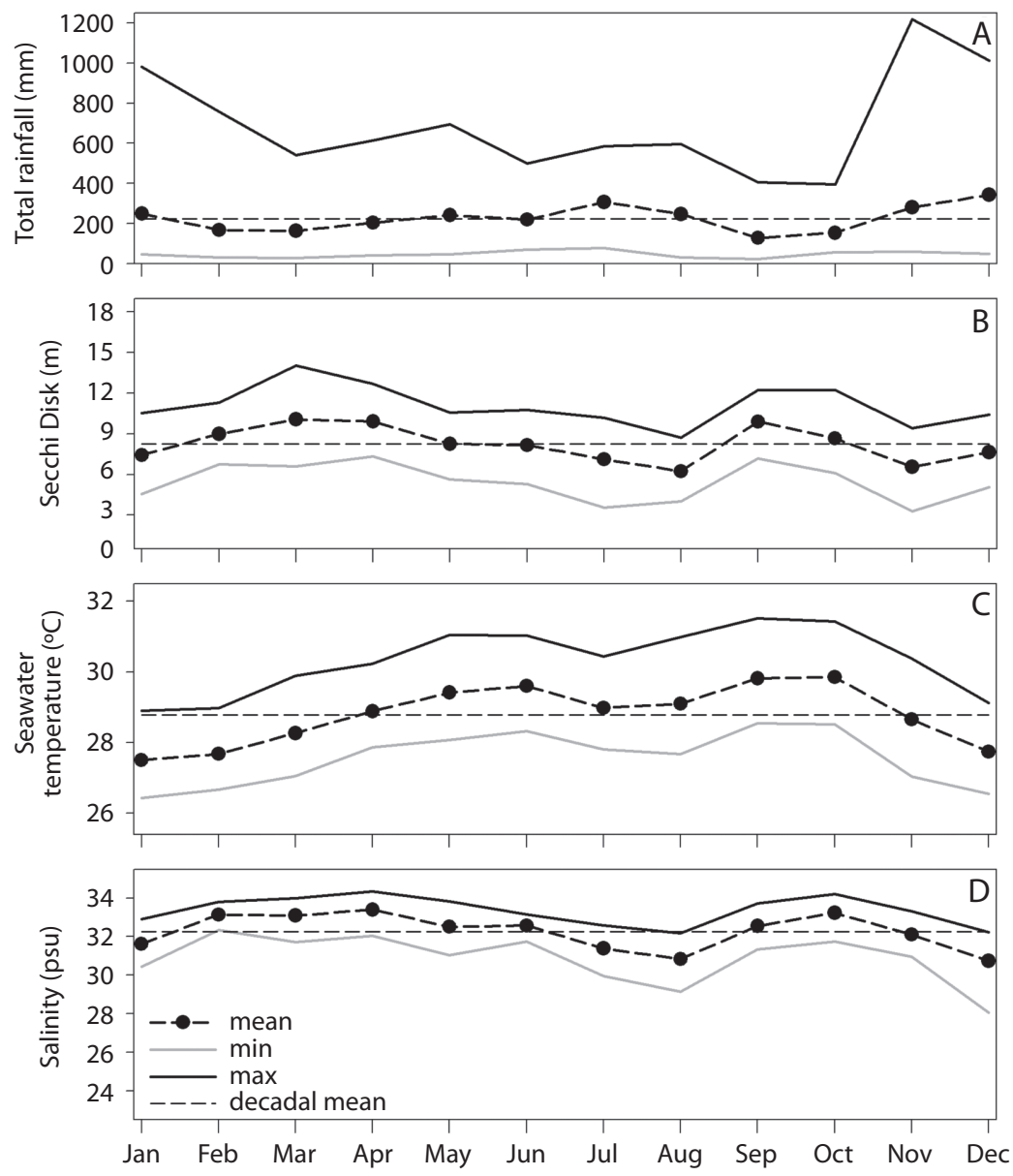

Fig. 3. Monthly mean (dotted line) and minimum/maximum values for (A) total rainfall, (B) Secchi disk depth, (C) seawater temperature, and (D) salinity (1999-2010). Horizontal dashed line is the correspondent decadal mean. 
TABLE 1

Spearman Rank Correlation coefficients for environmental variables (1999-2010)

\begin{tabular}{lccc} 
& Seawater temperature & Total rainfall & Salinity \\
Total rainfall & $(-0.25,0.004,130)$ & - & - \\
Salinity & $(0.25,0.006,127)$ & $(-0.47,0.000,127)$ & - \\
Water column visibility & $(0.21,0.020,128)$ & $(-0.50,0.000,128)$ & $(0.53,0.000,129)$ \\
\hline
\end{tabular}

*Numbers in parenthesis $=(\mathrm{r}, \mathrm{p}, \mathrm{n})$.

time-series that has been published as part of the CARICOMP project (Juman, 2005; Murdoch et al., 2007; Cortés, Fonseca, Nivia-Ruiz, Nielsen-Muñoz, Samper-Villarreal, \& Salas, 2010; Rodríguez-Martínez, Ruíz-Rentería, B. Van Tussenbroek, Barba-Santos, EscalanteMancera, \& Jordán-Garza, 2010; RodríguezRamírez, Garzón-Ferreira, Batista-Morales, Gil, Gómez-López, \& Gómez-Campo, 2010). Over the Wider Caribbean region, there are reports of a long-term decline of coastal ecosystems (coral reefs, seagrass meadows, and mangrove forests) due to natural but mostly due to anthropogenic stressors, climate change, runoff, over-fishing, pollution, and poor landuse practices being the most important (Guzman, 2003; Linton \& Fisher, 2004; Ogden, 2010; Cramer et al., 2012). Human population of Bocas del Toro has increased dramatically over the last ten years (Trombulak, 2006), leading to destruction of several hectares of mangrove forests and the lack of a sustainable urban plan for wastewater disposal (Trombulak, 2006).

There was an increase in total biomass and Leaf Area Index of T. testudinum from 1999 to 2010 in Bocas del Toro which could be a result of seawater temperature increase in the last decade. Positive correlation between SST with productivity $(\mathrm{p}=0.046, \mathrm{r}=0.39, \mathrm{df}=25)$ and standing crop $(\mathrm{p}=0.007, \mathrm{r}=0.51, \mathrm{df}=25)$ also support this hypothesis. Leaf Area Index increase is possibly a result of the increase in total biomass, to satisfy the metabolic requirements for plant growth (Enríquez \& Pantoja-Reyes, 2005). Lee, Park \& Kim (2007) report that optimum temperature for growth and photosynthesis for T. testudinum is $29^{\circ} \mathrm{C}$, almost the average temperature recorded in our time series $\left(28.79^{\circ} \mathrm{C}\right)$. Therefore, a further warming of the ocean could have a negative effect on turtlegrass meadows. Higher temperatures will increase their respiratory demands as well as microbial metabolism (Short \& Neckles, 1999; Duarte, 2002), this will favor the occurrence of anoxic conditions in the sediment (Borum, Pedersen, Greve, Frankovich, Zieman, \& Fourqurean, 2005). Also algal communities that already form part of the seagrass community might be benefited from this temperature increase, their overgrowth will limit the amount of light reaching the leaves (Short \& Neckles, 1999; Holmer, Wirachwong, \& Thomsen, 2011).

These scenarios are exacerbated given the presence of eutrophic conditions. Eutrophication as a consequence of coastal runoff constitutes a potential threat to turtlegrass productivity (Van Tussenbroek, Vonk, Stapel, Erftemeijer, Middelburg, \& Zieman, 2006). Fourqurean, Powell, Kenworthy, \& Zieman (1995) found that fertilization of turtlegrass meadows had a positive effect on the plants, with increased biomass even two years after fertilization. However, in the presence of other seagrass species (e.g., Halodule wrightii) standing crop of T. testudinum drastically dropped. Eutrophication also promotes abnormal phytoplankton blooms and macroalgae overgrowth which cannot be offset by fish-grazing (Gacia, Littler, \& Littler, 1999). Nutrient enrichment can also displace $T$. testudinum by other seagrass species (Tomasko \& Lapointe, 1991; Bachelet, Montaudouin, Auby, \& Labourg, 2000; Van Tussenbroek et al., 2006; Van Tussenbroek, 2011). 
The increase in biomass recorded during the last decade and the associated temperature increase are evidence of the progressive changes occurring in the Caribbean, particularly in Bocas del Toro. The Caribbean is experiencing eutrophication of coastal waters due to human activities since before the 1960's (Lewis, 1984; Wear, Sullivan, Moore, \& Millie, 1999; Gardner, Côte, Gill, Grant, \& Watkinson, 2003; Pandolfi, Bradbury, Sala, Hughes, Bjorndal, \& Cooke, 2003; Van Tussenbroek et al., 2006; Ogden, 2010; Rodríguez-Martínez et al., 2010, Cramer et al., 2012). Land clearing activities, overfishing, global warming, and an ineffective management of coastal resources are the current most important anthropogenic and natural stressors (Guzman, 2003, RodríguezMartínez et al. 2010, Cramer et al., 2012). It is imperative to continue efforts focused on mapping aereal extent of meadows (Wabnitz et al., 2008), its population dynamics (extension of vegetative genets and dispersal of sexual propagules), public awareness of the economic importance of healthy ecosystems (Nagelkerken et al., 2002; Tibbets, 2006) to foster integrative national management and conservation plans for the upcoming environmental changes.

\section{ACKNOWLEDGMENTS}

Authors wish to thank C. Guevara, A. Castillo, and P. Gondola for field and laboratory support during different parts of the project. The project was sponsored by the Smithsonian Tropical Research Institute. J. López-Calderón was supported by an internship awarded from the Smithsonian Tropical Research Institute and by CONACYT grant 41393 .

\section{RESUMEN}

El Programa de Productividad Costera Marina del Caribe (CARICOMP) fue iniciado en 1993 para estudiar interacciones regionales a largo plazo entre la tierra y el mar, tomando mediciones estandarizadas de productividad y biomasa de manglares, arrecifes de coral y pastos marinos. Desde 1999 mediciones continuas de parámetros de pasto marino (Thalassia testudinum) así como datos ambientales han sido registrados para el Caribe de Panamá.
Réplicas de estaciones fueron seleccionadas cerca del Instituto Smithsonian de Investigaciones Tropicales en Bocas del Toro. Núcleos de sedimento y cuadrantes fueron colocados para estimar biomasa y productividad, respectivamente. Valores promedio de productividad, biomasa foliar, tasa de recambio, biomasa total seca e Índice de Área Foliar fueron $1.74 \mathrm{gDW} / \mathrm{m}^{2} / \mathrm{d}, 66.6 \mathrm{gDW} / \mathrm{m}^{2}, 2.62 \% / \mathrm{d}$, $1481 \mathrm{gDW} / \mathrm{m}^{2}, \mathrm{y} 4.65$, respectivamente. La biomasa total seca (haces, rizomas y raíces) e Índice de Área Foliar de T. testudinum incrementaron significativamente durante el periodo de estudio. Valores promedio de lluvia total, profundidad de disco de Secchi, temperatura superficial del mar y salinidad fueron $3498 \mathrm{~mm}, 8.24 \mathrm{~m}, 28.79^{\circ} \mathrm{C}$, y $32.26 \mathrm{psu}$, respectivamente. La temperatura superficial del mar fue la única variable ambiental con un incremento estadísticamente significativo, de 1999 a 2010. La correlación entre la temperatura superficial del mar y los parámetros de T. testudinum (biomasa total y LAI) fueron tanto positivos como significativos. La población humana ha crecido dramáticamente durante los últimos diez años en la región de Bocas del Toro, incrementando la presión (deforestación, escorrentía, aguas negras) sobre los ecosistemas costeros (pastos marinos, manglares, arrecifes coralinos). Cambios en la abundancia de $T$. testudinum pueden estar ligados al calentamiento oceánico, como una consecuencia para satisfacer los requerimientos metabólicos de la planta, aunque es necesario analizar otros factores locales (reducción del pastoreo e incremento en la eutrofización). Un mayor calentamiento del océano puede tener efectos negativos en la población de T. testudinum, incrementando las demandas respiratorias y el metabolismo microbiano.

Palabras clave: Caribe, Panamá, CARICOMP, series temporales, productividad, Thalassia testudinum.

\section{REFERENCES}

Alcolado, P. M., Alleng, G., Bonair, K., Bone, D., Buchan, K., \& Bush, P. G. (2001). The Caribbean Coastal Marine Productivity Program (CARICOMP). Bulletin of Marine Science, 69(2), 819-829.

Aronson, R. B., MacIntyre, I. G., Wapnicks, C. M., \& O’Neill, M. W. (2004). Phase shifts, alternate states and the unprecedented convergence of two reef systems. Ecology, 85(7), 1876-1891.

Bachelet, G., Montaudouin, X., Auby, I., \& Labourg, P. J. (2000). Seasonal changes in macrophyte and macrozoobenthos assemblages in three coastal lagoons under varying degrees of eutrophication. ICES Journal of Marine Science, 57, 1495-1506.

Björk, M., Short, F., Mcleod, E., \& Beer, S. (2008). Managing seagrasses for resilience to climate change. Gland, Switzerland: IUCN.

Borum, J., Pedersen, O., Greve, T. M., Frankovich, A., Zieman, J. C., \& Fourqurean, J. W. (2005). The potential 
role of plant oxygen and sulphide dynamics in die-off events of the tropical seagrass, Thalassia testudinum. Journal of Ecology, 93, 148-158.

Burkholder, J. M., Tomasko, D. A., \& Touchette, B. W. (2007). Seagrasses and eutrophication. Journal of Experimental Marine Biology and Ecology, 350, 46-72.

CARICOMP. (2001). CARICOMP methods manual levels 1 and 2: manual of methods for mapping and monitoring of physical and biological parameters in the coastal zone of the caribbean. CARICOMP Data Management Center Centre for Marine Sciences University of the West Indies Mona, Kingston, Jamaica, 91.

Carruthers, T. J. B., Barnes, P. A. G., Jacome, G. E., \& Fourqurean, J. W. (2005). Lagoon scale processes in a coastally influenced Caribbean system: implications for the seagrass Thalassia testudinum. Caribbean Journal of Science, 41(3), 441-455.

Casares, F. A. \& Creed, J. C. (2008). Do small seagrasses enhance density, richness and biodiversity of macrofauna? Journal of Coastal Research, 24(3), 790-797.

Cortés, J., Fonseca, A. C., Nivia-Ruiz, J., Nielsen-Muñoz, V., Samper-Villarreal, J., \& Salas, E. (2010). Monitoring coral reefs, seagrasses and mangroves in Costa Rica (CARICOMP). Revista de Biología Tropical, 58(3), 1-22.

Cramer, K. L., Jackson, J. B. C., Angioletti, C. V., LeonardPingel, J., \& Guilderson, T. P. (2012). Anthropogenic mortality on coral reefs in Caribbean Panama predates coral disease and bleaching. Ecology Letters, 1-7. doi: 10.1111/j.1461-0248.2012.01768.x

Creed, J. C., Phillips, R. C., \& Tussenbroek, B. I. Van. (2003). The seagrasses of the Caribbean. In E. P. Green \& F. T. Short (Eds.), World Atlas of Seagrasses (pp. 234-242). Cambridge: UNEP-WCMC.

Cuevas, E., Liceaga-Correa, M., \& Garduño-Andrade, M. (2007). Spatial characterization of a foraging area for immature hawksbill turtles (Eretmochelys imbricata) in Yucatan, Mexico. Amphibia-Reptilia, 28, 337-346.

D’Croz, L., del Rosario, J. B., \& Góndola, P. (2005). The effect of fresh water runoff on the distribution of dissolved inorganic nutrients and plankton in the Bocas del Toro Archipelago, Caribbean Panama. Caribbean Journal of Science, 41(3), 414-429.

Duarte, C. M. (2002). The future of seagrass meadows. Environmental Conservation, 29(2), 192-206.

Duarte, C. M., \& Chiscano, C. L. (1999). Seagrass biomass and production: a reassessment. Aquatic Botany, 65, 159-174.

Duarte, C. M., Marbà, N., Gacia, E., Fourqurean, J. W., Beggins, J., \& Barrón, C. (2010). Seagrass community metabolism: assessing the carbon sink capacity of seagrass meadows. Global Biogeochemical Cycles, 24(GB4032), 1-8.

Enríquez, S., \& Pantoja-Reyes, N. I. (2005). Form-function analysis of the effect of canopy morphology on leaf self-shading in the seagrass Thalassia testudinum. Oecologia, 145, 235-243.

Erftemeijer, P. L. A., \& Robin-Lewis III, R. R. (2006). Environmental impacts of dredging on seagrasses: a review. Marine Pollution Bulletin, 52, 1553-1572.

Fonseca, A. C., Nielsen, V., \& Cortés, J. (2007). Monitoreo de pastos marinos en Perezoso, Cahuita, Costa Rica (sitio CARICOMP). Revista de Biología Tropical, 55(1), 55-66.

Fourqurean, J. W., Powell, G. V. N., Kenworthy, W. J., \& Zieman, J. C. (1995). The effects of long term manipulation of nutrient supply on competition between the seagrasses Thalassia testudinum and Halodule wrightii in Florida Bay. Oikos, 72(3), 349-358.

Fulweiler, R. W., Rabalais, N. N., \& Heiskanen, A. S. (2012). The eutrophication commandments. Marine Pollution Bulletin, 64, 1997-1999.

Gacia, E., Littler, M. M., \& Littler, D. S. (1999). An experimental test of the capacity of food web interactions (fish-epiphytes-seagrasses) to offset the negative consequences of eutrophication on seagrass communities. Estuarine, Coastal and Shelf Science, 48, 757-766.

Gardner, T. A., Côte, I. M., Gill, J. A., Grant, A., \& Watkinson, A. R. (2003). Long-term region-wide declines in Caribbean corals. Science, 301, 958-960.

Green, E. P., \& Short, F. T. (2003). World Atlas of Seagrasses. Berkley: University of California Press.

Green, S. O., \& Webber, D. F. (2003). The effects of varying levels of eutrophication on phytoplankton and seagrass (Thalassia testudinum) populations of the southeast coast of Jamaica. Bulletin of Marine Science, 73(2), 443-456.

Guzmán, H. M., \& Guevara, C. A. (1998). Arrecifes coralinos de Bocas del Toro, Panamá: I. Distribución, estructura y estado de conservación de los arrecifes continentales de la Laguna de Chiriquí y la Bahía Almirante. Revista de Biología Tropical, 46, 601-622.

Guzman, H. M. (2003). Caribbean coral reefs of Panama: present status and future perspectives. In J. Cortés (Ed.), Latin American Coral Reefs (pp. 241-274). Amsterdam: Elsevier.

Guzmán, H. M., Barnes, P. A. G., Lovelock, C. E., \& Feller, I. C. (2005). A site description of the CARICOMP mangrove, seagrass and coral reef sites in Bocas del Toro, Panama. Caribbean Journal of Science, 41(3), 430-440.

Halpern, B. S., Walbridge, S., Selkoe, K. A., Kappel, C. V., Micheli, F., \& D’Agrosa, C. (2008). A global map of 
human impact on marine ecosystems. Science, 319, 948-952.

Harborne, A. R., Mumby, P. J., Micheli, F., Perry, C. T., Dahlgren, C. P., \& Holmes, K. E. (2006). The functional value of Caribbean coral reef, seagrass and mangrove habitats to ecosystem processes. Advances in Marine Biology, 50, 57-189.

Heck, K. L., Jr., Hays, G., \& Orth, R. J. (2003). Critical evaluation of the nursery role hypothesis for seagrass meadows. Marine Ecology Progress Series, 253, 123-136.

Holmer, M., Wirachwong, P., \& Thomsen, M. S. (2011). Negative effects of stress-resistant drift algae and high temperature on a small ephemeral seagrass species. Marine Biology, 158, 297-309.

Juman, R. A. (2005). The structure and productivity of the Thalassia testudinum community in Bon Accord Lagoon, Tobago. Revista de Biología Tropical, 53(1), 219-227.

Kaufmann, K. W., \& Thompson, R. C. (2005). Water temperature variation and the meteorological and hydrographic environment of Bocas del Toro, Panama. Caribbean Journal of Science, 41(3), 392-413.

Kennedy, H., Beggins, J., Duarte, C. M., Fourqurean, J. W., Holmer, M., \& Marbà, N. (2010). Seagrass sediments as a global carbon sink: isotopic constraints. Global Biogeochemical Cycles, 24, 1-8. doi:10.1029/2010GB003848

Krupp, L. S., Cortés, J., \& Wolff, M. (2009). Growth dynamics and state of the seagrass Thalassia testudinum in the Gandoca-Manzanillo National Wildlife Refuge, Caribbean, Costa Rica. Revista de Biología Tropical, 57(Supl. 1), 187-201.

Lee, K. S., Park, S. R., \& Kim, Y. K. (2007). Effects of irradiance, temperature, and nutrients on growth dynamics of seagrasses: a review. Journal of Experimental Marine Biology and Ecology, 350, 144-175.

Lewis, J. B. (1984). The Acropora inheritance: a reinterpretation of the development of fringing reefs in Barbados, West Indies. Coral Reefs, 3, 117-122.

Linton, D., \& Fisher, T. (2004). CARICOMP Caribbean Coastal Marine Productivity Program 1993-2003. Kingston, Jamaica: Cent. Mar. Sci., Univ. West Indies.

Mumby, P. J., Edwards, A. J., Arias-González, E., Lindeman, K. C., Blackwell, P. G., \& Gall, A. (2004). Mangroves enhance the biomass of coral reef fish communities in the Caribbean. Nature, 427, 533-536.

Murdoch, T. J. T., Glasspool, A. F., Outerbridge, M., Ward, J., Manuel, S., \& Gray, J. (2007). Large-scale decline in offshore seagrass meadows in Bermuda. Marine Ecology Progress Series, 339, 123-130.

Nagelkerken, I., Roberts, C. M., Van der Velde, G., Dorenbosch, M., Van Riel, M. C., \& Cocheret de la
Morinière, E. (2002). How important are mangroves and seagrass beds for coral-reef fish? The nursery hypothesis tested on an island scale. Marine Ecology Progress Series, 244, 299-305.

Nagelkerken, I., \& Van der Velde, G. (2004). Relative importance of interlinked mangroves and seagrass beds as feeding habitats for juvenile reef fish on a Caribbean island. Marine Ecology Progress Series, 274, 153-159.

Nellemann, C., Corcoran, E., Duarte, C. M., Valdés, L., de Young, C., \& Fonseca, L. (2009). Blue Carbon: a rapid response assessment. United Nations Environment Programme: Grid-Arendal.

Ogden, J. C. (2010). Marine spatial planning (MSP): a first step to ecosystem-based management (EBM) in the Wider Caribbean. Revista de Biología Tropical, 58(3), 71-79.

Orth, R. J., Carruthers, T. J., Dennison, W. C., Duarte, C. M., Fourqurean, J. W., \& Heck, K. L. (2006). A global crisis for seagrass ecosystems. Bioscience, 56(12), 987-996.

Pandolfi, J. M., Bradbury, R. H., Sala, E., Hughes, T. P., Bjorndal, K. A., \& Cooke, R. G. (2003). Global trajectories of the long-term decline of coral reef ecosystems. Science, 301, 955-958.

Rodríguez-Martínez, R. E., Ruíz-Rentería, F., Van Tussenbroek, B. I., Barba-Santos, G., Escalante-Mancera, E., \& Jordán-Garza, G. (2010). Environmental state and tendencies of the Puerto Morelos CARICOMP site, Mexico. Revista de Biología Tropical, 58(3), 23-43.

Rodríguez-Ramírez, A., Garzón-Ferreira, J., Batista-Morales, A., Gil, D. L., Gómez-López, D. I., \& GómezCampo, K. (2010). Temporal patterns in coral reef, seagrass and mangrove communities from Chengue bay CARICOMP site (Colombia): 1993-2008. Revista de Biología Tropical, 58(3), 45-62.

Russell, B. D., Connell, S. D., Uthicke, S., Muehllehner, N., Fabricius, K. E., \& Hall-Spencer, J. M. (2013). Future seagrass beds: Can increased productivity lead to increased carbon storage? Marine Pollution Bulletin, in press.

Short, F. T., \& Burdick, D. M. (1996). Quantifying eelgrass habitat loss in relation to housing development and nitrogen loading in Waquoit Bay, Massachusetts. Estuaries, 19(3), 730-739.

Short, F. T., \& Neckles, H. A. (1999). The effects of global climate change on seagrasses. Aquatic Botany, 63, 169-196.

Short, F. T., Polidoro, B., Livingstone, S. R., Carpenter, K. E., Bandeira, S. B., \& Japar, S. (2011). Extinction risk assessment of the world's seagrass species. Biological Conservation, 144, 1961-1971. 
Tibbetts, J. (2006). Louisiana's Wetlands: a lesson in nature appreciation. Environmental Health Perspectives, 114(1), A40-A43.

Tomasko, D. A., \& Lapointe, B. E. (1991). Productivity and biomass of Thalassia testudinum as related to water column nutrient availability and epiphyte levels: field observations and experimental studies. Marine Ecology Progress Series, 35, 91-98.

Trombulak, S. E. (2006). Ley y Desorden: La participación, la política, y la planificación en el Archipiélago de Bocas del Toro (Vol. Paper 314). Available online digitalcollections.sit.edu/isp_collection/314

Van Tussenbroek, B. I., Vonk, J. A., Stapel, J., Erftemeijer, P. L. A., Middelburg, J. J., \& Zieman, J. C. (2006). The biology of Thalassia: paradigms and recent advances in research. In A. W. D. Larkum, R. J. Orth \& C. M. Duarte (Eds.), Seagrasses: Biology, Ecology and Conservation (pp. 409-439). Netherlands: Springer.

Van Tussenbroek, B. I. (2011). Dynamics of seagrasses and associated algae in coral reef lagoons. Hidrobiologica, 21, 293-310.

Van-Tussenbroek, B. I., Smith, S. R., Absten, M., Gerace, D. T., Alcolado, P., \& Gayle, P. M. H. (in press). CARICOMP seagrass monitoring: stability and change of seagrass communities throughout the Greater Caribbean.
Verweij, M. C., Nagelkerken, I., De Graaff, D., Peeters, M., Bakker, E. J., \& Van der Velde, G. (2006). Structure, food and shade attract juvenile coral reef fish to mangrove and seagrass habitats: a field experiment. Marine Ecology Progress Series, 306, 257-268.

Wabnitz, C. C., Andréfouët, S., Torres-Pulliza, D., MüllerKarger, F. E., \& Kramer, P. A. (2008). Regional-scale seagrass habitat mapping in the Wider Caribbean region using Landsat sensors: applications to conservation and ecology. Remote Sensing of Environment, $112,3455-3467$.

Watson, D. J. (1947). Comparative physiological studies on the growth of field crops: I. Variations in net assimilation rate and leaf area between species and varieties and within and between years. Annals of Botany N.S., 11, 41-76.

Waycott, M., Duarte, C. M., Carruthers, T. J. B., Orth, R. J., Dennison, W. C., \& Olyarnik, S. (2009). Accelerating loss of seagrasses across the globe threatens coastal ecosystems. Proceedings of the National Academy of Sciences, 106(30), 12377-12381.

Wear, D. J., Sullivan, M. J., Moore, A. D., \& Millie, D. F. (1999). Effects of water-column enrichment on the production dynamics of three seagrass species and their epiphytic algae. Marine Ecology Progress Series, 179, 201-213. 